\title{
The Improvement of Eco-school Students' Environmental Awareness in the Context of Education for Sustainable Development
}

\author{
Liga Lace-Jeruma ${ }^{1}$ BSc.; Rita Birzina ${ }^{2}$ Dr. paed. \\ University of Latvia, Latvia \\ liga_lace@inbox.lv¹; rita.birzina@1u.1v²
}

\begin{abstract}
Nowadays the humankind strives to reach higher and higher standards of living, disregarding the consumption of natural resources in their comfort and failing to think about what they will leave behind for the future generations. As the person's quality of life depends on the environment in which he lives, it is important to change his environmental awareness in the context of sustainable development. The younger is the person, the easier it is to develop environment-friendly behaviour in him. Eco-school is one of the ways of "greening" students' thinking. The aim of the study has been to find out how students' environmental awareness is developed in Biology lessons in Grade 7, basing on education for sustainability goals, objectives and cross-cutting sustainable development key competencies. A study has been performed in eco-school A in 2018 involving 38 students in it. During the study the year topic of the eco-school "Waste" was integrated in 11 Biology lessons using diverse teaching/learning methods; students were surveyed and they also did a test. The obtained data were processed using SPSS programme. The results showed that students' environmental awareness had improved: the level of knowledge and skills had increased; the choice of an environment-friendly behaviour had changed a little. However, the acquisition of one topic in one school subject is not sufficient to make students' environmental awareness change considerably in all cognitive, socio-emotional and behavioural domains.
\end{abstract}

Keywords: eco-school education, environmental awareness, education for sustainable development, Waste, biology.

\section{Introduction}

Nowadays the greatest part of the society is informed about different problems of the global environment - melting of glaciers, global warming, diminution of different habitats and extinction of species, rapid increase of human population, waste accumulation, shortage of food and fresh water and other environmental problems. The mankind in general strives for reaching higher living standards consuming more and more the natural resources and this has resulted in serious environmental problems that lead to a global catastrophe. Thus, it is necessary "to preserve the environment and improve it qualitatively not only for the present but also for the future generations" (Nagra, 2010, 153). This means that the life quality of any man depends upon the quality of the environment, therefore it is important for everyone to participate in activities in order to decrease the people's harmful impact on the nature. However, not always human actions are able to counterbalance people's negative impact on the nature because people do not fully comprehend the consequences of their action. As M. Barth and M. Rieckman point out "the fundamental reorientations and transformations in terms of sustainable development require a far-reaching change of thinking and acting in individuals and society as a whole" (Barth, Rieckman, 2016, 100). During the last two decades the improvement of environmental awareness on all levels of the society has become one of the key social aims. Young people more frequently face the principal problem of the society's development - to balance the economic growth and the environmental sustainability (Rychen, Salganik, 2003).

The school system provides the largest organized base for environmental education and action. With children in "the plastic age, school offers an effective instrument for imbedding in them the desirable environmental ethics" (Nagra, 2010, 154). It is the most effective to form students' environmental awareness in early years and it is important to direct their thinking and habits to the environment-friendly thinking. One of the ways, how the world handles the problems of sustainable development (SD) is the formation of eco-schools on the initiative of schools themselves. Eco-school can be considered a model which ensures schools to develop a whole-school approach to environmental education. The philosophy of an eco-school is to provide schools with tools and infrastructure to foster sustainability in their own environment and their own community, including students, teachers, parents (Eames, Cowie, Bolstad, 2008). It is important to pay attention to the relationship between pedagogical and environmentally correct architectonic projects of eco-schools. Thus, it is possible to use in practice different learning strategies in 
the environment that is adequate and appropriate for the students' age. Regarding the primary school level, children should acquire the experience "to know plants' and animals' needs, their habitats, how to reduce, reuse and recycle materials, how to keep ecosystems linked to forests and water" (Gadotti, 2010, 207).

Eco-schools in Latvia engage in gathering information about the problems in nature and educating children about them choosing the theme of the year annually in order to explore topical problems in the surrounding locality. The depth and diversity of integrating the eco-school's topic of the year depends on each teacher's willingness to participate and change the students' opinion and habits.

\section{The nature of an eco-school}

The International environmental education foundation or Foundation for environmental education in 1992 responding to solutions for sustainable development of education expressed in the United Nations (UN) conference that took place in Rio de Janeiro, developed the concept of Eco-schools (United Nations Conference, 1992). In 1994, Eco-schools started functioning in four European countries - United Kingdom, Greece, Germany and Denmark. In 2018, the movement of Eco-schools involved 51000 schools from 67 countries (Eco-school, 2014). The Environmental education foundation of Latvia has been managing the programme of Eco-schools in Latvia starting from 1998. At present 200 educational institutions from preschools to higher education institutions participate in the programme of Eco-schools in Latvia (Eko-skolu programma, 2012).

In order to organize successfully their work, schools' function according to the Seven Steps Framework: Form an Eco Committee; Carry out an Environmental Review; Action Plan; Monitor and Evaluate; Curriculum Work; Inform and Involve; Produce an Eco Code (Eco-school, 2014). Every year the Ecoschool works around a particular topic thoroughly focusing on it all through the year and trying to improve the results of the environment assessment and include this topic in the teaching/learning content. All in all, ten topics are implemented in Latvia - Energy, Waste, Food, Climate changes, School environment and vicinity, Water, Forest, Transport, Biological diversity and healthy lifestyle (Eko-skolu programma, 2012).

The Eco-school movement is very popular not only in Latvia but also in other countries. For instance, in Great Britain approximately $70 \%$ of schools have joined this programme (Tidy, 2013). The work of Ecoschools is being explored and the majority of studies has shown that Eco-schools are successfully functioning schools that improve both students' knowledge and attitude to the environment (Cincera, Krajhanzl, 2013; Eames, Cowie, Bolstad, 2008; Gadotti, 2010; Tidy, 2013; Taurina, 2015, 70; Spinola, 2015).

It is defined that in Latvia, when developing the teaching/learning content of the school, it should include topical environmental themes. One of such topics is waste. The content analysis of the standard of Biology as a school subject (Regulations Regarding..., 2014) shows that the topic of waste has been superficially included in the content, and little corresponds to the aims to change the students' thinking and also do not corresponds to competencies specified by Education for Sustainable Development 2030. The standard identifies five topics that are related to pollution and its impact on living organisms. The topic "Waste" included in the Eco-school programme envisaged four aims:

- to popularize such a choice of consumption and lifestyle that diminishes the production of waste to minimum;

- to reduce, reuse and recycle the waste produced by school as much as possible;

- to strengthen children and students' understanding about harmful consequences caused by leaving waste in nature;

- to implement activities to prevent littering in the vicinity of the Eco-school and other territories.

Only two aims correspond partly to the requirements set in the standard of biology as the school subject: diminishing of waste and reusing them, forming students' understanding about the harmful consequences caused by leaving waste in nature. This means that Eco-schools have to re-plan their teaching/learning content to include the topic of the year in their annual teaching plans to reach all four aims.

\section{Environmental awareness in the context of sustainable development}

General comprehensive schools of Latvia have been implementing the normative environmental education and partly also education for sustainable development since 1996 (Kakse, 2009). The aim of 
environmental education is the formation of environmental awareness and environmentally friendly and active behaviour. Environmental awareness helps to form positive attitudes about environmental issues, to be well aware of the environment and its related issues (Nagra, 2010) as well as to understand the negative role of human actions on the environment and promotes environmentally responsible behaviors (Karahan, Roehrig, 2015).

The concept of "sustainable development" was introduced in 1987 in the report Our Common Future by the World Commission on Environment and Development (Brundtland, 1987), defining sustainable development as the "meeting the needs of society without compromising the ability of future generations to meet their own needs". Education for sustainable development (ESD) is the 'older brother' of environmental education (Barth, Rieckman, 2016), and its aim is both to make people more responsible for future developments and to raise their awareness of problems related to sustainable development in all economic, social, environmental and cultural issues of future lives (Hoffmann, 2014; Sterling et al., 2017). Sustainability is understood as "a responsible action of individuals and societies towards a better future for all, locally and globally" (Bokova, 2015, 20) and education is "the key to the global integrated framework of sustainable development goals" (ibid, 5). The concept of sustainability has "an excellent educational component because the preservation of the environment depends on ecological awareness, which, in its turn, depends on education" (Gadotti, 2010, 205).

Problems of sustainable development should already be included in the teaching/learning process of the school (UNESCO, 2017a). The UN decade "Education for sustainable development" the aim of which was to integrate the principles, values and practical actions of sustainable development in education in all its aspects was implemented during the time period from 2002 till 2014 (Michelsen, Wells, 2017). The implementation of education for sustainable development is based on the approach of the constructivism theory - students themselves construct their knowledge and skills. The teacher is a guide in this process; the teacher helps, supports and shows the way how the student him/herself can acquire knowledge. The process, which has a clear attainable outcome, is important. Students in such constructively designed lessons develop their sustainable development skills as well as gain higher motivation to learn. It is advisable to make lessons differentiated and suitable for different students, offering equal education possibilities for all, which is one of the UN aims.

UNESCO (2017b) advises to include such critical issues in the curricula as climate changes, biological diversity, diminishing the threats of catastrophes, sustainable consumption and production. The teaching/learning environment should be interactive, the process - student centred. There is a wellconsidered learning environment both physical and virtual that encourages students to act for ensuring sustainability. It is envisaged to teach students the skills of "green workplaces" that will motivate them to take on a sustainable lifestyle. Besides the teaching/learning process should foresee a possibility for students to be - "global citizens" who can participate and take an active role solving locally and globally the problems of the world. As mentioned by T. Ichinose, this ensures "the fulfilment of ESD three essential aspects of holism: connecting the environmental, social, and economic dimensions of SD issues; integrating their past, present and future implications, and focusing on their local, regional, and global nature" (Ichinose, 2017, 37).

The intended learning outcome of such a teaching/learning process is the acquisition of learning and key competencies. UNESCO has defined 17 Sustainable Development Goals (SDG). For each SDG, learning objectives are described in the cognitive, socio-emotional and behavioural domains and 8 Key competencies for sustainability (Figure 1) (Rieckman, 2017).

Thus, ESD has been promoting "knowledge, skills, values and attitudes that empower learners to make informed decisions and take responsible actions for environmental integrity, economic viability and a just society" (Rieckman, 2018, 37), which also defines the formation of environmental awareness.

The aim of the study is to find out how students' environmental awareness (knowledge, skills and attitudes/behaviour) is developed in lessons of Biology in Grade 7 basing on ESD goals, objectives and cross-cutting competencies.

\section{Methodology}

The research question was identified, namely, how does students' environmental awareness improve when integrating the year topic of the Eco-school "Waste" in Biology lessons in Grade7. 


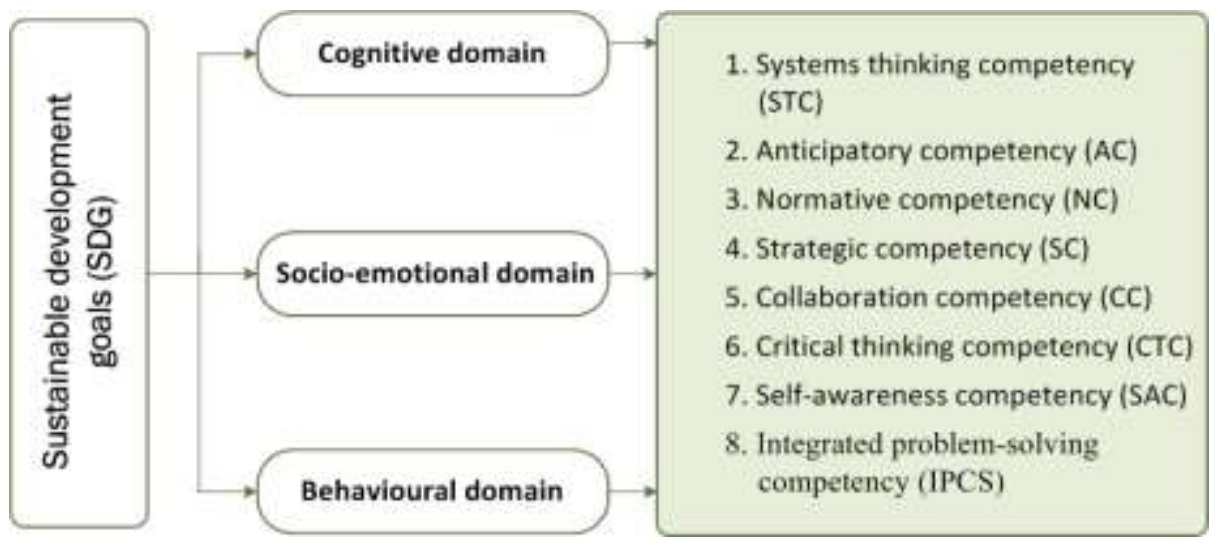

Figure 1. Approach of sustainable development competencies for attaining sustainable development goals.

The study has been performed to find out how students' environmental awareness develops if diverse teaching/learning methods based on ESD goals, objectives and cross-cutting SD key competencies are used in the lessons. The study was organized in school A and 38 students participated in it. The study was organized in three stages: Preparation, Implementation and Assessment (Figure 2).
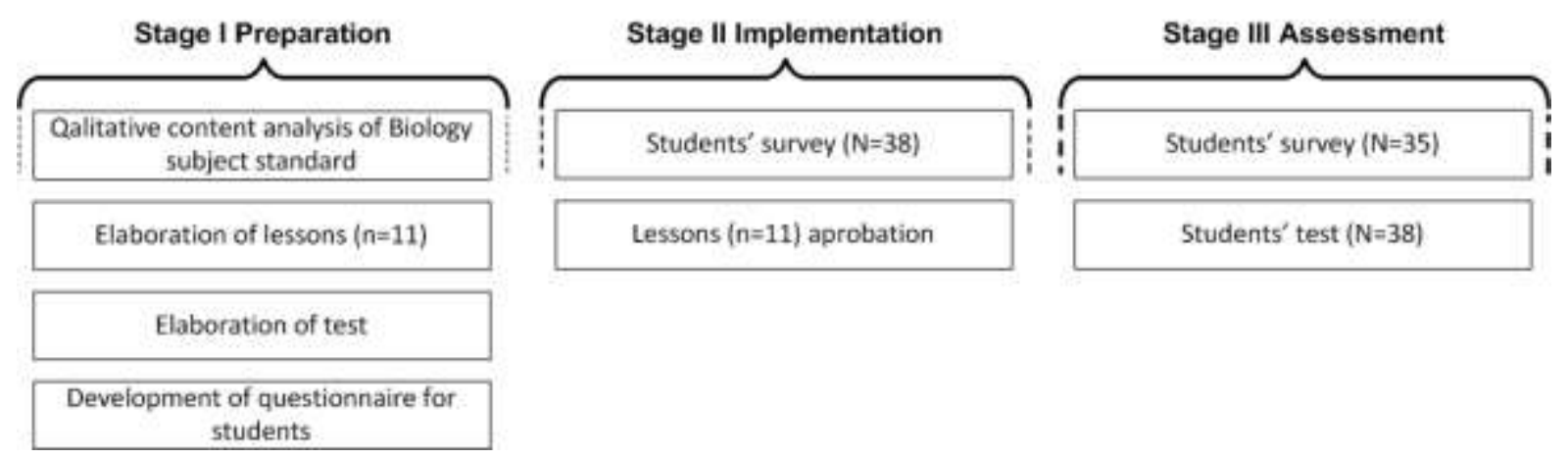

Figure 2. Stages of the present study.

During Stage I Preparation, 11 lessons were fully designed, a test was prepared and a questionnaire for students was developed.

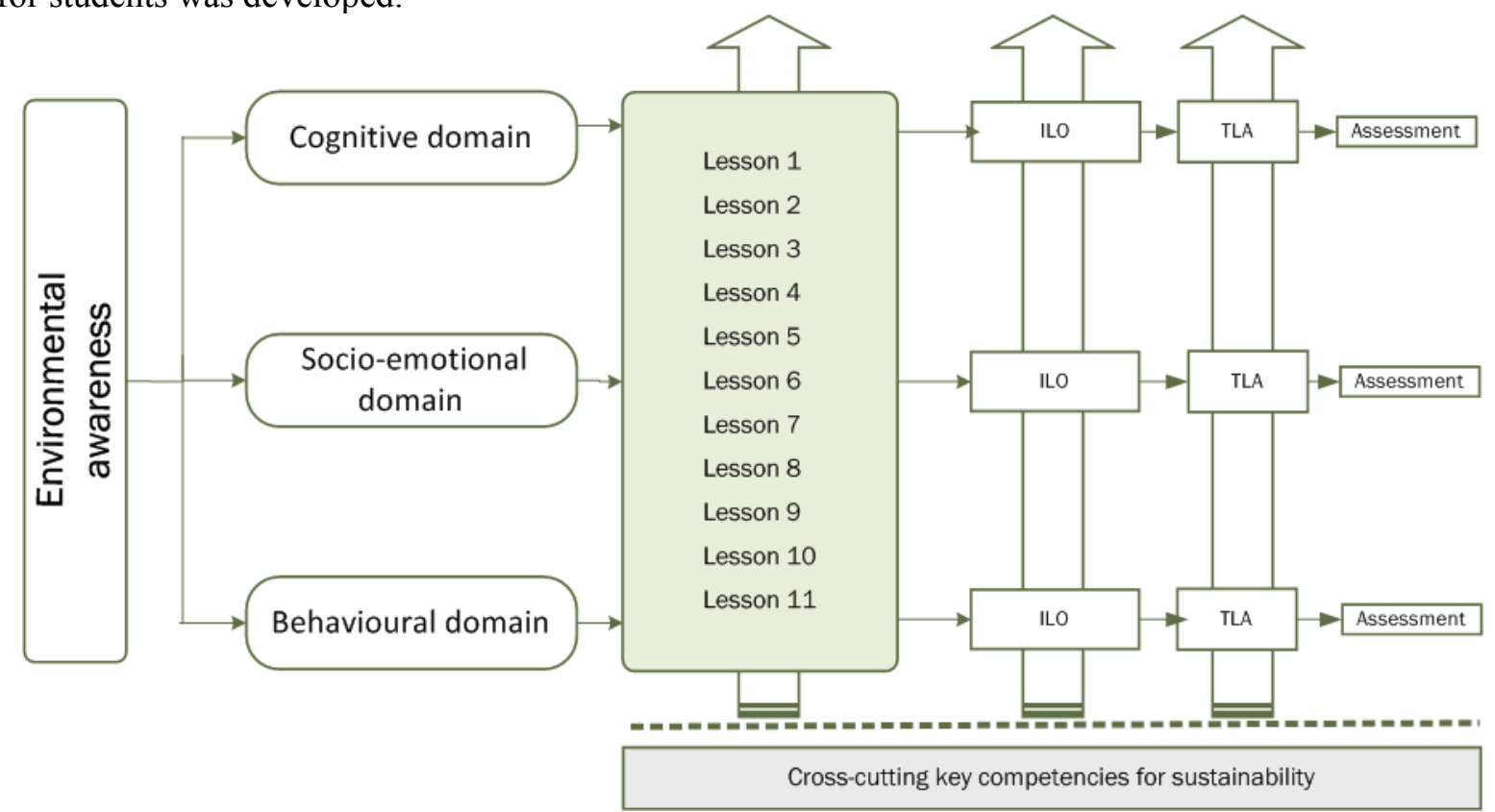

Figure 3. The competency approach for sustainable development in the lesson design. 
Lessons were designed based on the competency approach for sustainable development (Figure 3). Each topic of the lesson envisaged to improve students' environmental awareness (Table 1), using diverse teaching learning activities (TLA) to reach specific learning objectives in the cognitive, socio-emotional and behavioural domains, defining intended learning outcomes (ILO) in constructive alignment approach (Biggs, Tang, 2011) and basing on cross-cutting key competencies for SD.

Table 1

Teaching learning activities implemented in lessons

\begin{tabular}{|c|c|c|}
\hline Lessons & Teaching learning activities & $\begin{array}{c}\text { SD } \\
\text { competencies }\end{array}$ \\
\hline $\begin{array}{l}\text { Lesson } 1 \text {. Theoretical exploration of } \\
\text { ecosystems }\end{array}$ & Project making & $\mathrm{CC}, \mathrm{STC}$ \\
\hline Lesson 2. Diversity of ecosystems & Gallery method & $\mathrm{CC}$ \\
\hline Lesson 3. Diversity of ecosystems & Gallery method & $\mathrm{CC}$ \\
\hline Lesson 4. Virtual laboratory work & Virtual research work & STC \\
\hline $\begin{array}{l}\text { Lesson } 5 \text {. Threat to ecosystems- } \\
\text { invasive species and waste }\end{array}$ & $\begin{array}{l}\text { Problem solving: Four corners method } \\
\text { and Fish-bone method }\end{array}$ & IPSC, CC, SAC \\
\hline $\begin{array}{l}\text { Lesson 6. A court session "Invasive } \\
\text { plant - Sosnovskis' (Siberian) } \\
\text { hogweed" }\end{array}$ & Role play & $\mathrm{NC}$ \\
\hline Lesson 7. Protection of plants & $\begin{array}{l}\text { Work with sources of information, } \\
\text { producing infographics }\end{array}$ & $\mathrm{CC}, \mathrm{STC}$ \\
\hline Lesson 8. Protection of plants & Work with the text, planning the event & $\mathrm{SC}, \mathrm{CC}$ \\
\hline Lesson 9. Man-made ecosystems & Work with the text, creative work & STC \\
\hline $\begin{array}{l}\text { Lesson } 10 . \text { Models of ecosystems and } \\
\text { the society }\end{array}$ & Planning of the future ecosystem & $\mathrm{AC}, \mathrm{IPSC}$ \\
\hline Lesson 11. Summary on ecosystems & Doing tasks in work stations & STC \\
\hline
\end{tabular}

In order to find out students' opinions about the improvement of students' knowledge (cognitive domain), skills, attitudes (socio-emotional domain) and behaviour (behaviour domain) in the context of ESD, when integrating the Eco-school's topic of the year, a questionnaire was developed; it was used in surveying students before the acquisition of the topic "Ecosystems" and after the conducted 11 lessons. The questionnaire included open (6) and closed (5) questions. Open questions aimed at finding out students' knowledge and skills. Closed questions on the 3-point Likert scale (1-disagree, 3 -agree) were directed towards learning students' attitude/behaviour.

At this stage a test "The diversity of plants in ecosystems and its preservation" was also prepared; it included two higher cognitive level items on the topic "Waste". Students had to use the problem-solving approach in one of the items, namely, the pollution of the ecosystem with waste, and in the other - to model the future school 2030 as an ecosystem basing on the principles "from cradle to cradle" and "zero waste".

Stage II Implementation included surveying students before the acquisition of the topic "Ecosystems" and after the conducted 11 Biology lessons.

Stage III Assessment. A repeated survey was organized and a test was written after the topic had been acquired.

\section{Results and Discussions}

In order to find out how students' environmental awareness is developed in Biology lessons basing on ESD goals, objectives and cross-cutting key competencies, students' responses to the questions included in the questionnaire and their results in the test have been analysed. Cronbach's alpha for the socioemotional domain and behaviour domain items were 0.754. Kolmogorov-Smirnov's test helped to identify that the sample did not respond to a normal distribution. Mann Whitney U-test, Chi-square test 
did not show statistically significant differences between students' responses before and after the pedagogical intervention therefore data of descriptive statistics will be further analysed.

Table 2

Results obtained in open questions: characterising of students' knowledge, skills and attitudes

\begin{tabular}{|c|c|c|c|c|}
\hline $\begin{array}{c}\text { Category } \\
\text { (total units } \\
\text { of } \\
\text { meaning) }\end{array}$ & Subcategories & $\begin{array}{c}\text { Percent } \\
\text { of } \\
\text { meaning } \\
\text { (Before) }\end{array}$ & $\begin{array}{l}\text { Percent } \\
\text { of } \\
\text { meaning } \\
\text { (After) }\end{array}$ & Students' answers \\
\hline \multirow{13}{*}{$\begin{array}{l}\text { Cognitive } \\
\text { domain: } \\
\text { Knowledge } \\
(38)\end{array}$} & \multirow[t]{2}{*}{ What is waste? } & 77 & 94 & $\begin{array}{l}\text { Things that people do not need } \\
\text { anymore, that people leave behind. }\end{array}$ \\
\hline & & 21 & 6 & Pollution. \\
\hline & \multirow{3}{*}{$\begin{array}{l}\text { What kinds of } \\
\text { waste do you } \\
\text { know? }\end{array}$} & 76 & 71 & Waste produced by households. \\
\hline & & 7 & 8 & Industrial waste. \\
\hline & & 5 & 1 & Special waste. \\
\hline & \multirow{4}{*}{$\begin{array}{l}\text { What global } \\
\text { environmental } \\
\text { problems related } \\
\text { to waste have you } \\
\text { heard of? }\end{array}$} & 21 & 23 & $\begin{array}{l}\text { There are environment problems } \\
\text { (pollution of the nature). }\end{array}$ \\
\hline & & 21 & 23 & Global warming takes place. \\
\hline & & 16 & 2 & Have not heard of any problems. \\
\hline & & 8 & 18 & $\begin{array}{l}\text { Animals die or suffer due to waste in the } \\
\text { nature. }\end{array}$ \\
\hline & \multirow{4}{*}{$\begin{array}{l}\text { What } \\
\text { environmental } \\
\text { problems related to } \\
\text { waste in Latvia } \\
\text { have you heard of? }\end{array}$} & 45 & 8 & Have not heard of any problems. \\
\hline & & 18 & 33 & Nature (forests and waters) is littered. \\
\hline & & 3 & 15 & $\begin{array}{l}\text { Animals are endangered because of } \\
\text { waste. }\end{array}$ \\
\hline & & 0 & 20 & $\begin{array}{l}\text { Recreation and public places are } \\
\text { littered. }\end{array}$ \\
\hline \multirow{4}{*}{$\begin{array}{l}\text { Practical } \\
\text { Skills } \\
(38)\end{array}$} & \multirow{4}{*}{$\begin{array}{l}\text { How is waste } \\
\text { sorted in your } \\
\text { family/household? }\end{array}$} & 20 & 15 & Do not sort waste. \\
\hline & & 17 & 15 & Sort waste paper. \\
\hline & & 14 & 18 & Sort glass. \\
\hline & & 20 & 17 & Sort plastic materials. \\
\hline \multirow{4}{*}{$\begin{array}{l}\text { Socio- } \\
\text { emotional } \\
\text { domain: } \\
\text { Attitudes } \\
(38)\end{array}$} & \multirow{4}{*}{$\begin{array}{l}\text { What do you do in } \\
\text { your everyday life } \\
\text { to decrease the } \\
\text { formation of } \\
\text { waste? }\end{array}$} & 31 & 13 & Do nothing. \\
\hline & & 31 & 30 & $\begin{array}{l}\text { Do not pollute the nature - put waste in } \\
\text { waste bins, not litter around. }\end{array}$ \\
\hline & & 28 & 25 & Sort waste. \\
\hline & & 0 & 13 & $\begin{array}{l}\text { Avoid taking plastic bags in the shops, } \\
\text { use plastic bags repeatedly. }\end{array}$ \\
\hline
\end{tabular}

Students' knowledge about waste is mainly connected with the real-life experience. The majority of them consider that waste is what people have produced and no longer use, and relate the concept "waste" mainly to the domestic waste.

Relatively many students before starting the acquisition of the topic have not heard anything about different environmental problems either in Latvia or in the world - problems in the world $16 \%$ and in Latvia $45 \%$. After studying the topic students were able to mention more environmental problems both in Latvia and in the world, as well as the number of students who had not heard about problems with the waste in the world had decreased $-2 \%$, and Latvia $-8 \%$.

The habits of sorting the waste had not changed particularly after the acquisition of the topic; however, it should be pointed out that students' everyday activities had changed after the acquisition of the topic - 
there were fewer students who did nothing at all (the number decreased from $31 \%$ to $13 \%$ ), and $13 \%$ of students started to refrain from taking plastic bags in the shops and use regularly the cotton bags.

Table 3

Results obtained in closed questions: characterising of students' opinions assessing their actions

\begin{tabular}{|c|c|c|c|c|c|c|}
\hline \multirow{2}{*}{$\begin{array}{l}\text { Items concerning socio-emotional } \\
\text { and behavioural domain } \\
\text { Likert scale units }\end{array}$} & \multicolumn{3}{|c|}{ Before $(\%)$} & \multicolumn{3}{|c|}{ After $(\%)$} \\
\hline & 1 & 2 & 3 & 1 & 2 & 3 \\
\hline How important is it to sort waste? & 0 & 42 & 58 & 0 & 40 & 60 \\
\hline $\begin{array}{l}\text { How do you evaluate your knowledge about sorting } \\
\text { waste? }\end{array}$ & 3 & 74 & 24 & 0 & 66 & 34 \\
\hline How much do waste problems worry you? & 14 & 51 & 35 & 6 & 69 & 26 \\
\hline $\begin{array}{l}\text { How ready are you to change your habits in order to } \\
\text { lessen waste problems? }\end{array}$ & 8 & 60 & 32 & 3 & 60 & 37 \\
\hline $\begin{array}{l}\text { How important is each person's participation in } \\
\text { decreasing the amount of waste? }\end{array}$ & 6 & 44 & 50 & 0 & 49 & 52 \\
\hline
\end{tabular}

Students' answers in items of socio-emotional and behavioural domain, after the acquisition of the topic show that the number of radically negative answers ( 1 - disagree) has decreased. The number of positive answers (3 - agree) has not increased notably; however, it could be explained by the fact that students probably have become more critical towards themselves. Still, the majority of students are aware of the importance of sorting waste $(60 \%)$, besides at least a half of students consider that each person's participation in diminishing the amount of waste is important.

\section{Results of the test}

Thirty-eight students write the test after studying the topic. The mean statistical indicators of the test results are asymmetrical with a negative offset because the mode $(M o=7)$ is bigger than the mean arithmetic $(M=6.3)$ and median $(M d n=6)$, which means that more students have received the mark that is lower than the value of the mode.

Each item of the test has been statistically analysed and the obtained data are summarized in Table 4 . Five items included questions of average difficulty level (0.48-0.64), and three items had been relatively easy $(0.67 \%-0.78 \%)$. None of the items had been too easy $(\mathrm{p}>0.85)$. The resolution had been calculated from students' eight highest results and eight lowest results. The resolution for three items had been low, four had an acceptable level of resolution and one - high resolution.

Table 4

\section{Evaluation of test items}

\begin{tabular}{l|rrrrrrrr}
\hline \multicolumn{1}{c|}{ Number of the item } & \multicolumn{1}{c}{$\mathbf{1 .}$} & $\mathbf{2 .}$ & $\mathbf{3 .}$ & $\mathbf{4 .}$ & $\mathbf{5 .}$ & $\mathbf{6 .}$ & $\mathbf{7 .}$ & $\mathbf{8 .}$ \\
\hline $\begin{array}{l}\text { Maximum number of points to } \\
\text { be received }\end{array}$ & 5 & 11 & 8 & 3 & 6 & 6 & 6 & 5 \\
$\begin{array}{l}\text { Average number of points } \\
\text { received }\end{array}$ & 2.78 & 7.08 & 3.82 & 2.35 & 4.39 & 3.14 & 3.41 & 3.33 \\
$\begin{array}{l}\text { Mean percentage performance } \\
(\%)\end{array}$ & 56 & 64 & 48 & 78 & 73 & 52 & 57 & 67 \\
$\begin{array}{l}\text { Level of difficulty (p) } \\
\begin{array}{l}\text { Resolution (D) } \\
\hline\end{array}\end{array}$ \\
\hline
\end{tabular}

Two items out of eight included in the test were related to the topic of waste, namely, the fourth and eighth. Seventy-eight percent of students had done the fourth item very well; however, from the point of view of the difficulty level, it was the easiest item in the test $(p=0.78)$, and its resolution had been rather low $(+0.21)$. Thus, it shows that students in the lesson on the problem solving about waste in ecosystems have gained good knowledge. 
The eighth item was similar to the item from Lesson 10 about the models of ecosystems and their impact on the society (Table 1). This, too, was the third easiest item of the test according to students' results $(p=0.67)$, its resolution is average $(\mathrm{D}=+0.45)$. Students have coped with this item successfully, and this allows concluding indirectly that implementing the lesson about the modelling of the future school the majority of students have reached the aim of the lesson- modelling of the School 2030 as an ecosystem applying the principles "from cradle to cradle" and "zero waste".

\section{Conclusions}

The integration of the topic "Waste" in the acquisition of Biology in Grade 7 is a big challenge and the eco-school is an appropriate environment for its implementation. It requires from the teacher "stepping out" from the frame of the standard of Biology as a school subject and teacher's initiative in lesson designing including diverse interactive teaching/learning methods in order to reach the ESD specific learning objectives in knowledge, socio-emotional and behavioural domains and defining intended learning outcomes, basing on cross-cutting sustainable development key competencies. Students' high assessment in solving items related to the topic of waste serves as evidence of the knowledge acquisition. The results of the survey, too, show that the level of students' knowledge has increased: the results of students' questionnairing before studying the topic were lower than after the approbation of the lessons. This means that their knowledge about the environmental problems is increasing. It is more difficult to judge about the improvement of their skills and attitudes. The above said means that the formation of the environmental awareness is a long-term process that is connected with the change of students' attitude and behaviour Students' environmental awareness cannot improve if there are no external conditions that would promote it. These are teachers at schools who can facilitate the improvement of the awareness developing strategies for teaching and learning processes towards the improvement of ESD learning; however, it is not sufficient with one topic and one school subject for the students to change significantly environmental awareness.

\section{Bibliography}

1. Barth M., Rieckmann M. (2016). State of the art in research on higher education for sustainable development. In: M. Barth, G. Michelsen, M. Rieckmann, I. Thomas (Eds.), Routledge Handbook of Higher Education for Sustainable Development. London: Routledge, 100-113.

2. Biggs J.B., Tang C. (2011). Teaching for quality learning at university. ( $4^{\text {th }}$ ed.). Maidenhead, UK: Open University Press.

3. Brundtland G. (1987). Report of the 1987 World Commission on Environment and Development: Our common future. Oslo: United Nations, 1-9.

4. Cincera J., Krajhanzl J. (2013). Eco-Schools: what factors influence pupils' action competence for pro-environmental behaviour? Journal of Cleaner Production, 61(25), 117-121.

5. Eames C.W., Cowie B., Bolstad R. (2008). An evaluation of characteristics of environmental education practice in New Zealand schools. Environmental Education Research, 14(1), 35-51.

6. Eco-Schools. (2014). About Eco-Schools. Retrieved from http://www.ecoschools.global/howdoes-it-work

7. Eko-skolu programma (Eco School program). (2012). Retrieved from http://www.videsfonds.lv/lv/ekoskolas (in Latvian)

8. Gadotti M. (2010). Reorienting education practices towards sustainability. Journal of education for sustainable development, 4(2), 203-211.

9. Hoffmann T. (2014). Is there a specific ESD methodology? Schools for sustainability a resource Toolkit for Teacher Training, 1-8.

10. Ichinose T. (2017). An analysis of transformation of teaching and learning of Japanese Schools that significantly addressed education for sustainable development. Journal of Teacher Education for Sustainability, 19(2), 36-50.

11. Regulations Regarding the State Standard in Basic Education, the Subjects of Study Standards in Basic Education and Model Basic Educational Programmes. (2014). Retrieved from https://likumi.lv/ta/en/en/id/268342-regulations-regarding-the-state-standard-in-basic-educationthe-subjects-of-study-standards-in-basic-education-and-model-basic-educational-programmes

12. Kakse V. (2009). Izglitiba ilgtspejigai attistībai Latvijas visparizglitojosas skolas (Education for Sustainable Development in comprehensive schools of Latvia). In M. Klavins, J. Zaloksnis (Eds.), 
Vides izglitiba augstskola. (Environmental Education in Universities). Riga: LU Akademiskais apgads, 198-206. (in Latvian)

13. Karahan E., Roehrig G.H. (2015). Constructing media artifacts in a social constructivist environment to enhance students' environmental awareness and activism. Journal of Science Education and Technology, 24(1), 103-118.

14. Michelsen G., Wells P.J. (Eds.). (2017). A Decade of progress on education for sustainable development: reflections from the UNESCO Chairs Programme. Paris: UNESCO Publishing. Retrieved from https://www.iau-hesd.net/sites/default/files/documents/unesco-esd.pdf

15. Nagra V. (2010). Environmental education awareness among school teachers. The Environmentalist, 30(2), 153-162.

16. Rieckman M. (2017). Education for Sustainable Development Goals: Learning Objectives. Paris: UNESCO Publishing.

17. Rieckman M. (2018). Learning to transform the world: key competencies in ESD. In A. Leicht, J. Heiss, W.J. Byun (Eds.), Issues and trends in Education for Sustainable Development, 39-60. Paris: UNESCO Publishing.

18. Rychen D.S., Salganik L.H. (2003). Highlights from the OECD Project Definition and Selection Competencies: Theoretical and Conceptual Foundations (DeSeCo). Cambridge: Hogrefe Huber Publishers.

19. Spinola H. (2015). Environmental literacy comparison between students taught in Eco-schools and ordinary schools in the Madeira Island region of Portugal. Science Education International, 26(3), 392-413.

20. Sterling S., Glasser H., Rieckmann M., Warwick, P. (2017). "More than scaling up": a critical and practical inquiry into operationalizing sustainability competencies. In P. Blaze Corcoran, J. Weakland, A. Wals (Eds.), Envisioning futures for environmental and sustainability education, 153 - 168. Wageningen: Wageningen Academic Publishers.

21. Taurina A. (2015). Pre-school Age Child Treatment and Awareness about Conservancy of Nature. In V. Dislere (Ed.), The Proceedings of the International Scientific Conference Rural Environment. Education. Personality (REEP), 8. Jelgava: LLU TF, 65-73. Retrieved from http://lufb.llu.lv/conference/REEP/2015/Latvia-Univ-Agricult-REEP-2015proceedings.pdf

22. Tidy K.B. (2013). Eco-schools England. Exploring success to inform a new horizon. Retrieved from http://www.keepbritaintidy.org/sites/default/files/resources/KBT_Eco-

Schools_Informing_a_new_horizon_2013.pdf

23. United Nations Conference on Environment and Development. Agenda 21. (1992). Rio de Janerio, Brazil: United Nations Sustainable Development. Retrieved from https://sustainabledevelopment.un.org/content/documents/Agenda21.pdf

24. UNESCO. (2017a). Education for Sustainable Development. Retrieved from https://en.unesco.org/themes/education-sustainable-development

25. UNESCO. (2017b). What is Education for Sustainable Development? Retrieved from https://en.unesco.org/themes/education-sustainable-development/what-is-esd 